\title{
The Impact of Cultural Diversity on Mosques in Malaysia
}

\author{
Mansoureh Ebrahimi ${ }^{1} \&$ Kamaruzaman Yusoff ${ }^{1}$ \\ ${ }^{1}$ Faculty of Islamic Civilization, Universiti Teknologi Malaysia, Johor Bahro, Malaysia \\ Correspondence: Mansoureh Ebrahimi, Faculty of Islamic Civilization, Universiti Teknologi Malaysia, Johor \\ Bahro, Malaysia, E-mail: mansoureh@utm.my; suriebrahimi@gmail.com
}

Received: May 22, 2018

doi:10.5539/ach.v10n2p45
Accepted: May 26, 2018

Online Published: July 16, 2018

URL: http://dx.doi.org/10.5539/ach.v10n2p45

\begin{abstract}
According to Malaysia Town and Country Planning Guideline and Standards (2002), two major considerations related to mosque usage and management are sufficient areas for both building and adjacent open space. As a sacred place for prostration to Almighty God, individually or in groups, mosque architecture has evolved considerably, from very simple designs and functions to more sophisticated forms and layouts. In Malaysia, various races have significantly influenced mosque design and function. The present work describes this evolution in terms of well-known mosques via qualitative observations and documentation, from earliest to latest architectural developments. Our findings demonstrate that architectural evolution and/or transformation did not alter the mosque's main function from an Islamic perspective. Nonetheless, designs and structure did benefit usage, to include the attraction of tourists.
\end{abstract}

Keywords: Islamic architecture, mosque, Malay, Chinese, Indian, Malaysia

\section{Introduction}

The term 'Mosque' derives from the French word, mosquée, but originates with the Spanish term, 'mezquita'. The Arabic term, 'masjid', derives from 'sajd' (Gazalba 1975, 108), which means 'sujud' (prostration), and 'sejadah' or 'prayer mat' (Nasir, 1984). The combination of these words means an 'act of prostration on a prayer mat', a Muslim necessity when performing prayers.

Although prayers can be performed anywhere on earth that is clean and pure, as a principal religious building reserved for the worship of Allah, the mosque is vital to communal prayer and usually boasts one or more minarets. According to Al-Quran: "And indeed the mosque is for (the worship of) Allah alone, so call not on anyone else besides Allah" (Surah A1-Jinn [72:18]). As a significant symbol for all Muslims, it is 'full of modesty' and is especially designed for human beings to express gratitude and to praise their Creator for their very existence (Latif, 2012). The mosque assists in the creation of social solidarity and communal empathy while aiming to guide attendees towoards moral perfection and the practice of approaching God.

Depending on local needs, mosques vary in size to accommodate five daily prayers and at least forty congregants for Friday prayers. In its simplest form, a mosque is built around a single horizontal axis, the qibla, which is a line that passes invisibly through middle of the floor and issues from the front most wall (the qibla wall) on a perpendicular axis directed towards the Ka'aba in Mecca.

The first mosque was the $Q u b a$ Mosque, built during the life of prophet Muhammad. In addition to daily worship, mosques serve many functions (Allia et al. 2013; Manja \& Ahmad, 1995) including as administrative centre for public relations and courts while also providing Islamic education and for the dissemination of Islamic knowledge. Mosques are found everywhere in the world and although architecture has developed tremendously over the centuries (Shah, 2014), they all share basic architecture components as follows: haram, qibla wall, sahn (courtyard), riwaq (arcades), mihrab (prayer niche in the qibla wall), minbar (sermon podium), minaret and maqsura. These components now include the dikka (a tribune for leaders), the kursi (Al-Quran holder), the maida (ablution pool), and the qubbah (dome), each with temporal and regional characteristics (Y. Ahmad, 2013).

According to Malaysia Town and Country Planning Guideline and Standards (2002), two major considerations related to mosque usage and management are sufficient areas for both building and adjacent open space.

Early mosques contained prayer halls with an open courtyard and covered area where the former area ensured contact with the sky (Hitam \& Talib, 2005). The mosque's interior must also evoke serenity via the use of diffused 
lighting. Light in covered areas came from the sun through several apertures, including an opening in the dome above the mihrab bay; again allowing direct connection with the sky. In this manner, light was reflected by the dome's shell and gently diffused into the prayer hall; thus providing a subtle and variegated display to remind congregants of their divine duty to worship Allah.

Additionally, the word, 'architecture', as adopted by different languages, derives from the Latin, architecture, and the Greek, arkhitekton, for 'architect'. As the art of building design and construction, architecture describes a process of planning, designing and constructing buildings, to include physical structures as well as forms, spaces and ambience in a manner that reflects functional, technical, social, environmental and aesthetic considerations. Architectural works are commonly identified as cultural symbols and actual works of art. Historically, surviving architectural structures often identify civilizations. It also appears that architecture is intimately linked with the history of art and the explicit religious concepts that guided design aesthetics as well as public function. Moreover, both exterior and interior settings often showcased the development of visual art.

Islamic architecture came to incorporate a broad range of diverse styles from Islam's inception to contemporary periods, all of which affected design and structure in several Muslim cultures. Essential principals of Islamic architecture are found in the Mosque, the Tomb, the Palace, and the Fort, the School and sundry urban buildings. For all types, Islam's architectural domain developed a rich terminology, used also for less important buildings such as public baths, fountains and local structures. (WHEBN0000276104, World Heritage Encyclopedia)

Islamic architecture bears sophistication and witnesses exalted levels of authority that Muslim architects had reached during the Golden Age $\left(8^{\text {th }}-13^{\text {th }}\right.$ centuries). These builders bequeathed numerous scientific and technological advancements to the modern world. Whether mosque, palace or ordinary house, they reflected style and use of space that conveyed profound devotion to Islam's worldview.

As a sacred place for prostration to Almighty God, individually or in groups, mosque architecture has evolved considerably, from very simple designs and functions to more sophisticated forms and layouts. In Malaysia, various races have significantly influenced mosque design and function. The present work describes this evolution in terms of well-known mosques via qualitative observations and documentation, from earliest to latest architectural developments. Our findings demonstrate that architectural evolution and/or transformation did not alter the mosque's main function from an Islamic perspective. Nonetheless, designs and structure did benefit usage, to include the attraction of tourists.

\section{History of Islamic Architecture}

In 630 CE, Prophet Muhammad's army conquered Mecca, which had been ruled by Bani Quraish. The holy Ka'aba was then reconstructed and re-dedicated to Islam before his death in $632 \mathrm{CE}$. According to Agius:

Prophetic traditions offer evidence of regular sea traffic between Arabia and Abyssinia (modern Eritrea): one reports that a ship owned by a Byzantine trader was wrecked at the port of Jeddah and that local builders used her timber to cover the roof of the Ka'aba in Mecca; another relates that the first Muslim converts sailed on merchant ships to Abyssinia; a third states that the ruler of Abyssinia sent a party of 60 persons on board a ship in 6/627, that never reached the coast of Arabia; a fourth reports that in $7 / 628$, Habiba, the Prophet's wife, was among a number of Quraysh emigrants who sailed from Abyssinia to Jar on the Arabian littoral (Agius, 2008, p. 64).

These records are considered among the first major works on Islamic architecture. Paintings of Jesus, Mary, Abraham and the prophets, of angels and trees had also been done. But later, during Islam's Golden Age, and based on certain hadith, the use of such portraits in Islamic architecture was specifically banned, including all depictions of humans and animals. With regard to the spread of Islam around Mecca in the 7th century, the first requirement was always to establish a house of worship. At the time, mosques were simple buildings based on the Prophet's own house.

Historically, the Juatha mosque in Saudi Arabia is a fine example from the period of Prophet Muhammad. The first political association of Islamic Architecture began during the Rashidin Caliphates (632-661). The Omayyads (661-750) absorbed elements of Byzantine and Sassanid architecture that combined western and eastern styles. Diverse decor with Islamic motifs included mosaics, wall paintings as well as sculptured and carved reliefs, all of which characterized the Omayyad era, during which the mihrab was added to the fundamental mosque design. The mosque built in Medina by Al-Walid was the first to have a mihrab, which immediately became a standard feature that represented the place of the Prophet during prayer.

Persian and Central Asian styles influenced the Abbasids (750-1513) who added courtyards. The mosque of alMansur in Baghdad was among the earliest of this type. Moreover, the two famous mosques of Samarra had spiral 
minarets. The first was the Great Mosque of Samarra built by al-Mutawakkil (256 X $\left.139 \mathrm{~m}^{2}\right)$, decorated with marble and glass, having a flat wooden roof supported by columns. The second was the Abu Dulaf mosque, with a prayer hall of arcades on rectangular brick piers running at right angles to the qibla wall.

"Islamic art and architecture in Andalusia developed their own characteristics and styles like in Iran" (Gu, 2013, p. 165). In $785 \mathrm{CE}$, Islamic architects from the Iberian Peninsula and North Africa began building the Great Mosque of Córdoba (Mezquita), which is known for its impressive interior arches (Gu, 2013, p. 166). The Bab Mardum in Toledo and the caliphate city of Medina's Azahara are two smaller examples with a similar style.

Moorish architecture has deep roots in the Arab tradition of architecture and design established during the first caliphate of the Umayyads in the Levant, circa 660 CE. In Damascus there are well preserved examples of fine Arab-Islamic design and geometrics, including the Carmen, the typical Damascene house that opens on the inside to a fountain as the house's centerpiece (Gu, 2013, pp. 166-167).

Fatimid architecture in Egypt followed Tulunid techniques, using similar materials while also developing an independent style. The first congregational mosque was at al-Azhar (969-973) in Cairo, and is decorated with Kufi inscriptions, beautifully designed with very high standards (Gu, 2013, 161). "The Mosque of al-Hakim'(996-1013) is a great example of Fatimid architecture and played a crucial role in the religious and political role of the Fatimid Caliphate" (Yalman, 2001). During Mamluk rule (1250-1517 A.D.), Islamic art and architecture flourished in Cairo. Ibn Khaldūn praised Cairo as "the capital of the world, the garden of the universe, the meeting place of mankind" (Fischel, 1952).

Hence, for a thousand years, Islamic art and architecture has advanced and presently demonstrates increasing potential with Islamic architectural designs internationally. In Malaysia, KLCC is an obvious example of a modern structure with an Islamic design.

\section{Role, Function and Facilities of the Mosque}

In Apart from worship, mosques serve various functions including education, religious propagation, as well as political and social services (Abbasali, 2011). Mosques have been used for political, economic, military, religion, education, publishing and training purposes and are considered by many to be the unifying heart of the Ummah (Hossein, 2014).

According to Malaysia Town and Country Planning Guideline and Standards (2002), under Planning Guidelines for Muslim Places of Worship, the mosque's four major functions are: (i) a public place of worship; (ii) an institution for religious education and resources; (iii) a community centre for meetings, collections, rest and relaxation in a landscaped area; and (iv) tourist attractions. Hence, the Mosque holds an integrated focus on communal services at the core of cultural, political, social, economic and educational activities.

The podium (minbar) is to the right of the mihrab, is usually a platform with steps from which the Imam delivers sermons (Khutbah). Facility management makes possible operations, maintainence, renovations and adaptations of buildings and infrastructure in support of primary objectives. According to Najafi and Mustafa (2012), facilities and equipment should support public religious and social activities by providing conditions that enhance religious activities. A survey by Najafi and Sharif (2011) reported that a mosque's most sited features of importance were its physical features, indicating that a mosque's facilities' management group is important.

The role and function of a mosque is preeminently as a place of public worship that provides worship space and ablution facilities as well as rooms for imams and muezzins, in addition to prayer equipment such as sejadah, telekung, Al-Quran and tasbih. A mosque's secondary role is to function as an institution of religious education and resources, which also requires spaces for study, teaching and lecturing as well for a library, Islamic information and open spaces for reading. Lastly, as a community centre, space is needed for meetings and collections (e.g., zakat), as well for celebrations, events and the implementation of charitable programs.

Researchers have listed several types of facilities, including a good clean worship hall and comfortable worship equipment (Roslan, 2007; Nawawi et al., 2007); air conditioning, carpet, good lighting and ventilation, PA and LCD systems (Ismail et al., 2007; Yuseri et al., 2007; Nawawi et al., 2007), and a well-maintained ablution and toilet area (Roslan, 2007).

\section{Mosque Architecture in Malaysia}

Interestingly, mosque architecture in Malaysia has not only been influenced by time and region but also by multiethnic cultural influences that involved a substantial diffusion of various traditions throughout the country. According to a prominent Malaysian architect, Dr. Ghafar Ahmad, colonialism, climate, technology and political environments have been major factors that influenced mosque architecture in Malaysia (A. G. Ahmad, 1999). 
The writers observed two general aspects indicating that mosque design and architecture were racially influenced in Malaysia. It was important to select different typologies for spaces and buildings to adequately describe these impacts. For our purposes, major racial groups in Malaysia were confined to Malay, Chinese and Indian. Moreover, we chose nine mosques for their respective design features for discussion. These are set in four categories as follows:

1. Malay: Kampung Laut Mosque (Nilam Puri, Kelantan);

2. Chinese: Tengkera Mosque (Melaka: Chinese/Javanese); Kampung Kling Mosque (Melaka); Kampung Hulu Mosque (Melaka);

3. Indian: Kapitan Keling Mosque (Penang); Jamek Mosque (KL);

4. Modern: Sultan Salahudin Abdul Aziz Shah Mosque (Shah Alam); Crystal Mosque (Terengganu).

The earliest Malaysian mosques functioned as places of prayer and hold substantial historical significance. However, opinions remain divided on how Islam came to the Malay World. Not a few scholars claim it began in Malacca with Muslim merchants from India, the Middle East and China during the 15th Century. Under guidance from the Malay sultanate, each ethic group also imported a myriad of unique architectural designs (Hassan, 2010). In this section, several early mosques with different architectural designs are discussed.

\subsection{Traditional Malay Style Mosque}

The term 'traditional' is used to emphasize the influence of Malay art on architectural design prior to colonial impositions. Built in the 1730's, the Kampung Laut Mosque is one of the earliest traditional Malay mosques and is believed to be the oldest surviving mosque in Malaysia. It has a three-tiered roof supported by four main pillars (Figure 1). Its architecture is remarkable and remains an impressive work and study for modern architects because its entire structure was built without a single nail (Venugopal, 2012).

This unique structure is said to be similar to the Demak mosque in Jawa, the Kuno mosque in Champa, and the Wadi Hussein mosque in Thailand. Its design exhibits all the elements of traditional Malay architecture, including 'Chengal' hardwood timber columns and the 'Singhorra' clay-tiled roof (Hassan and Nawawi, 2014). Nevertheless, the roof's structure is similar to Hindu and Buddhist Chandi. This similarity is due to the dominion of Hindus in the Malay Peninsula prior to Islam's arrival. The layered roof is designed to provide gaps for air ventilation and natural lighting. Several developments were made in stages to expand the prayer area while also adding an attic and increasing support columns (to twenty) during renovations (Hassan, 2010). A similar design is found at the Papan Mosque in Perak; the only difference being the two-tiered roof (Johar et al. 2010).

\subsection{Chinese Style Mosque}

Most old mosques in Malacca have strong Sino-impressions. Although Malay heritage eventually conquered local mosque architecture, Malaysia's long and close ties with Chinese and Chinese architecture have also left their marks on the mosque. Examples include the basic square plan and Malay-Hindu influenced multi-layered roof (Figure 2), retained as thatched roofing was changed to ceramic tiles and walls to brick, along with a crown-like shape (Hassan, 2010).

Tranquerah Mosque (Masjid Tengkera) is a mosque that distinctly shows Chinese influence. It is recorded as the second oldest mosque in Malaysia, built in 1728 with a fusion of Nusantara and Chinese architecture. Its minaret shows a most obvious Chinese design, being assembled in the shape of a pagoda. The mosque's entrance is also identical to the entrance of a typical Chinese temple (King, 2012). The same minaret design is seen at Masjid Kampung Keling where the introduction of Chinese architecture is ornamentally elaborated. Kampung Hulu Mosque is another example of mosque with the Chinese architecture. Usually, such beautifications show the lotus flower or dragon and can be found on the minbar or on top of the roof. Other mosques displaying Chinese influence are Majid Tanjung Alai, Masjid Bukit Piatu, and Masjid Peringgit (Ismail \& Yusof, 2013). Although most mosques in Malacca were designed with strong influences from Hindu and Buddhist typologies, they still fulfill Islamic requirements without deviating from fundamental functions. 

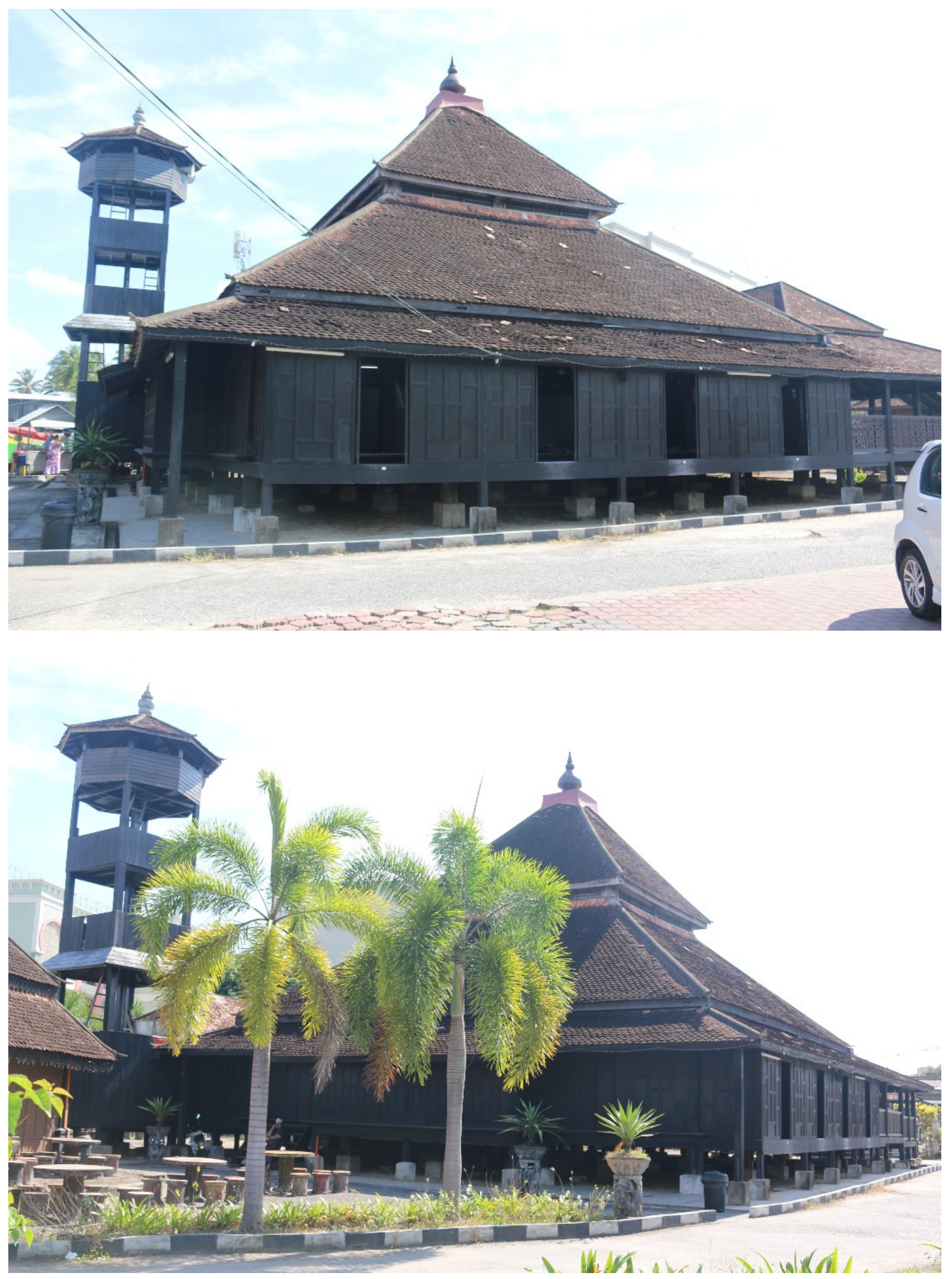

Figure 1. Kampung Laut Mosque (Nilam Puri, Kelantan) 


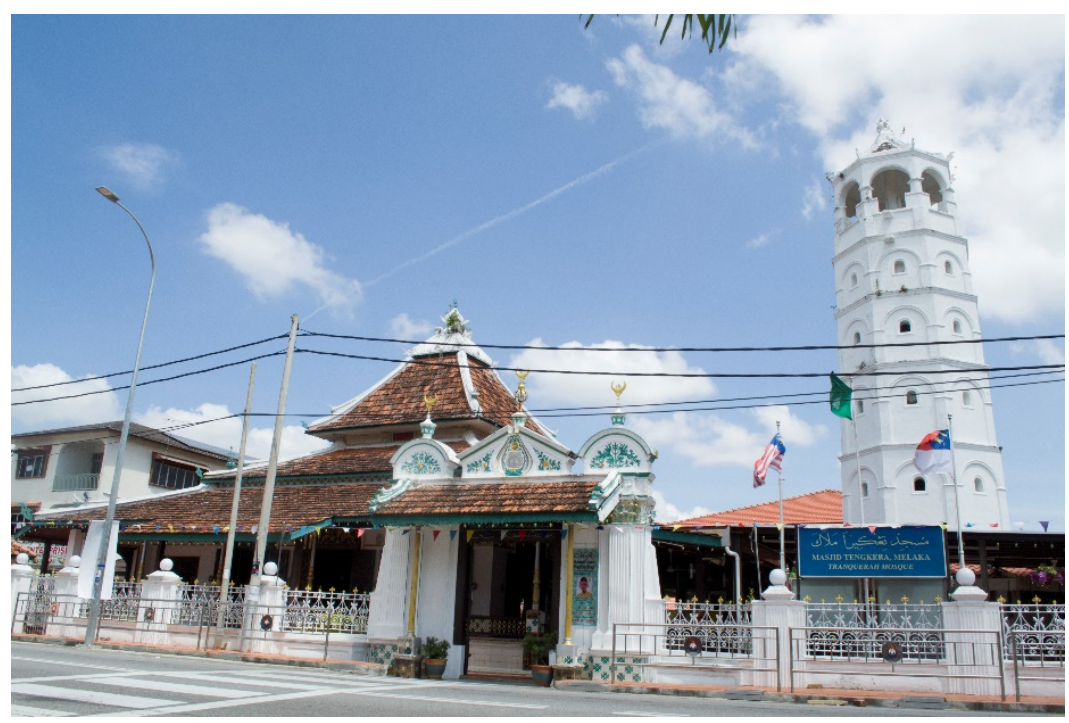

Figure 2. (a) Masjid Tengkera Melaka (Tranquerah Mosque)

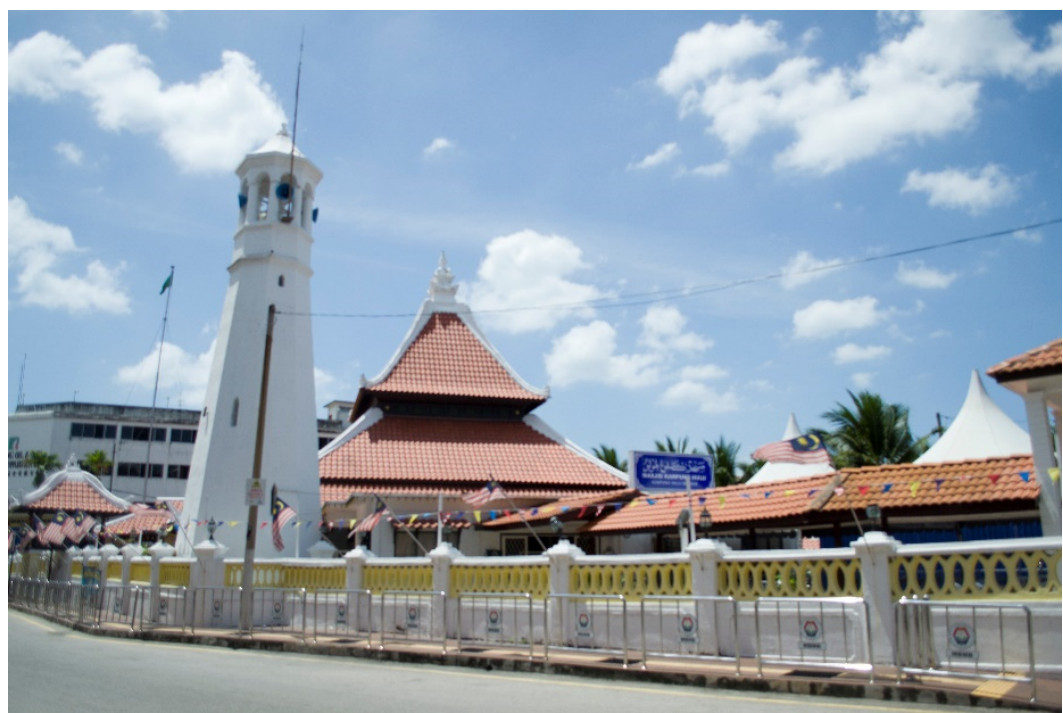

Figure 2. (b) Masjid Kampung Keling (Kampung Kling Mosque)

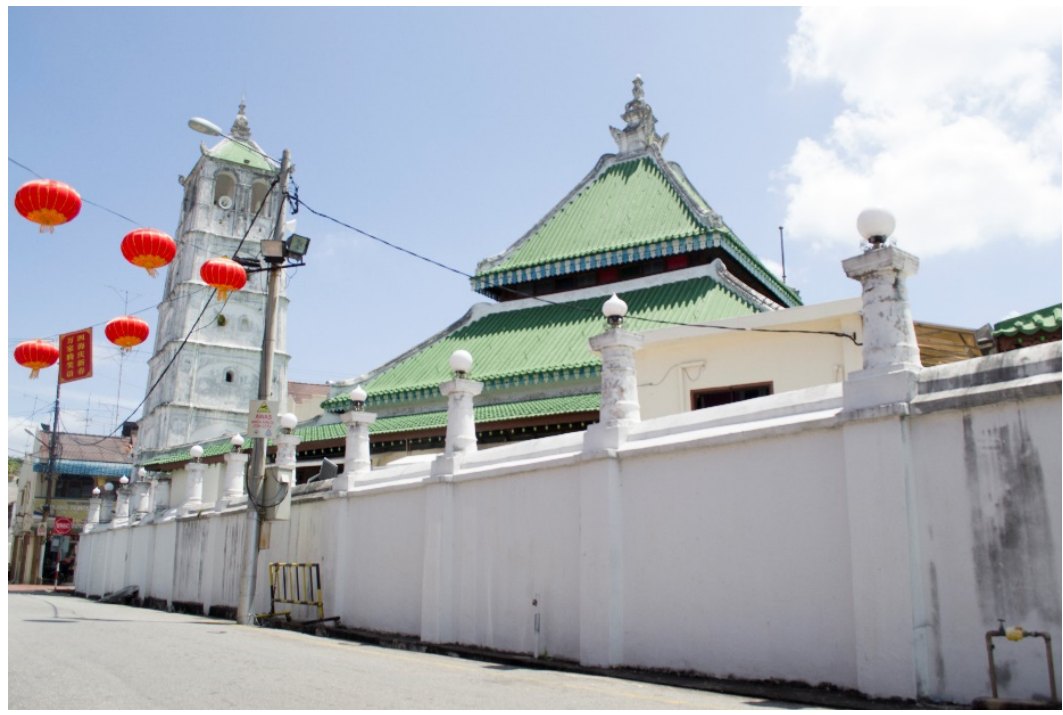

Figure 2. (c) Masjid Kampung Hulu (Kampung Hulu Mosque) 


\subsection{South Indian Style Mosque}

The arrival of Indian merchants had little impact on the design of architecture in Malaysia. However, people from Southern India did introduce Indian art to local mosque designs. One example is the Kapitan Keling Mosque in the middle of Melaka's Heritage trail. 'Keling' refers to Southern Indian men who married local Malays. The mosque was named after Captain (Kapitan) Caudeer Mohudeen, the leader of Kelings at the time. Built in 1748 and renovated in 1908, it retains original structure and design. Large Moghul-style (onion-shaped) domes, crescent and star, and an Indian-Islamic minaret, all set Kapitan Keling Mosque apart from previously cited structures (Figure 3). Nonetheless, its floor plan remained square, just like the Tengkera and other mosques with pyramidal roofing (Vlatseas, 1990).

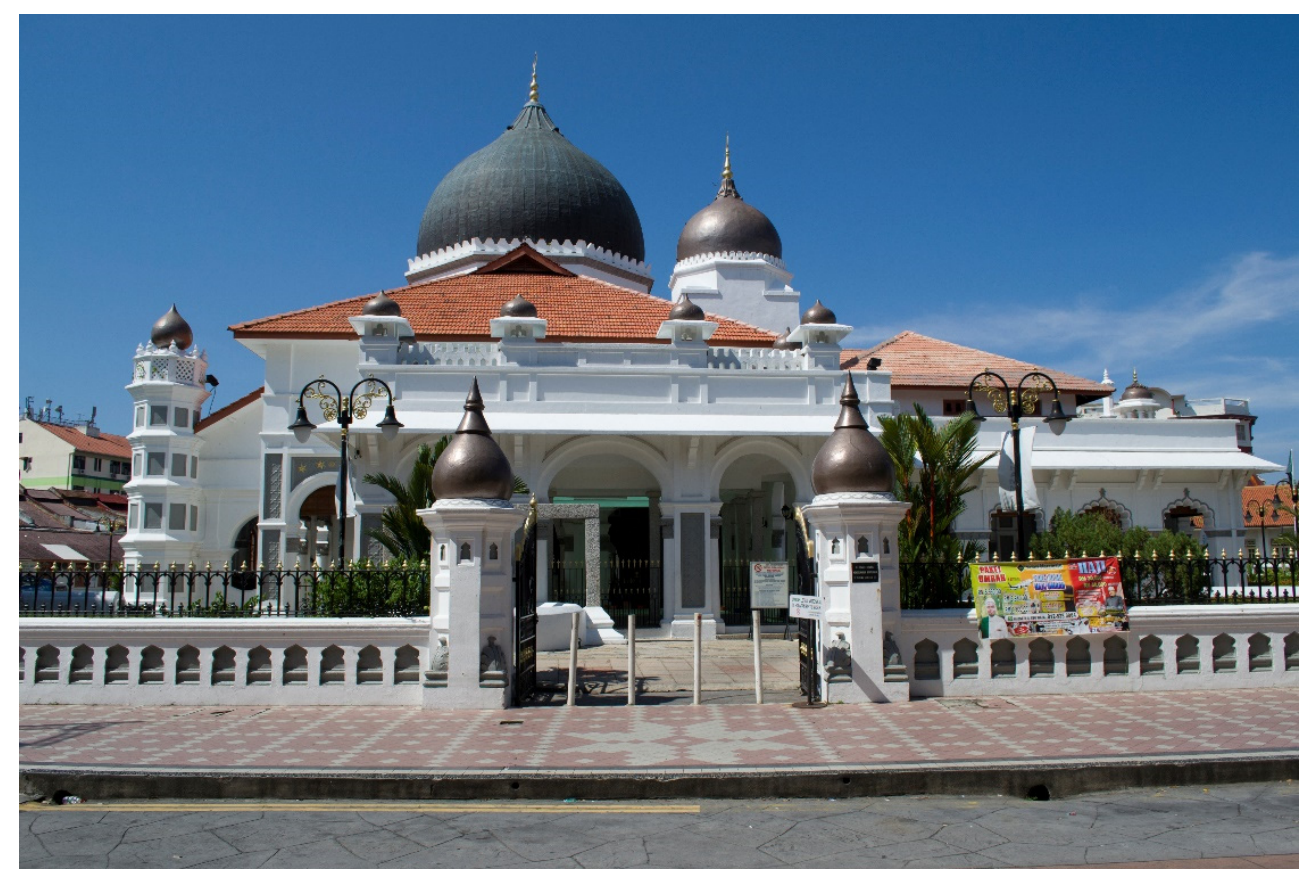

Figure 3. (a) Kapitan Keling Mosque and brick fence (frontal view).

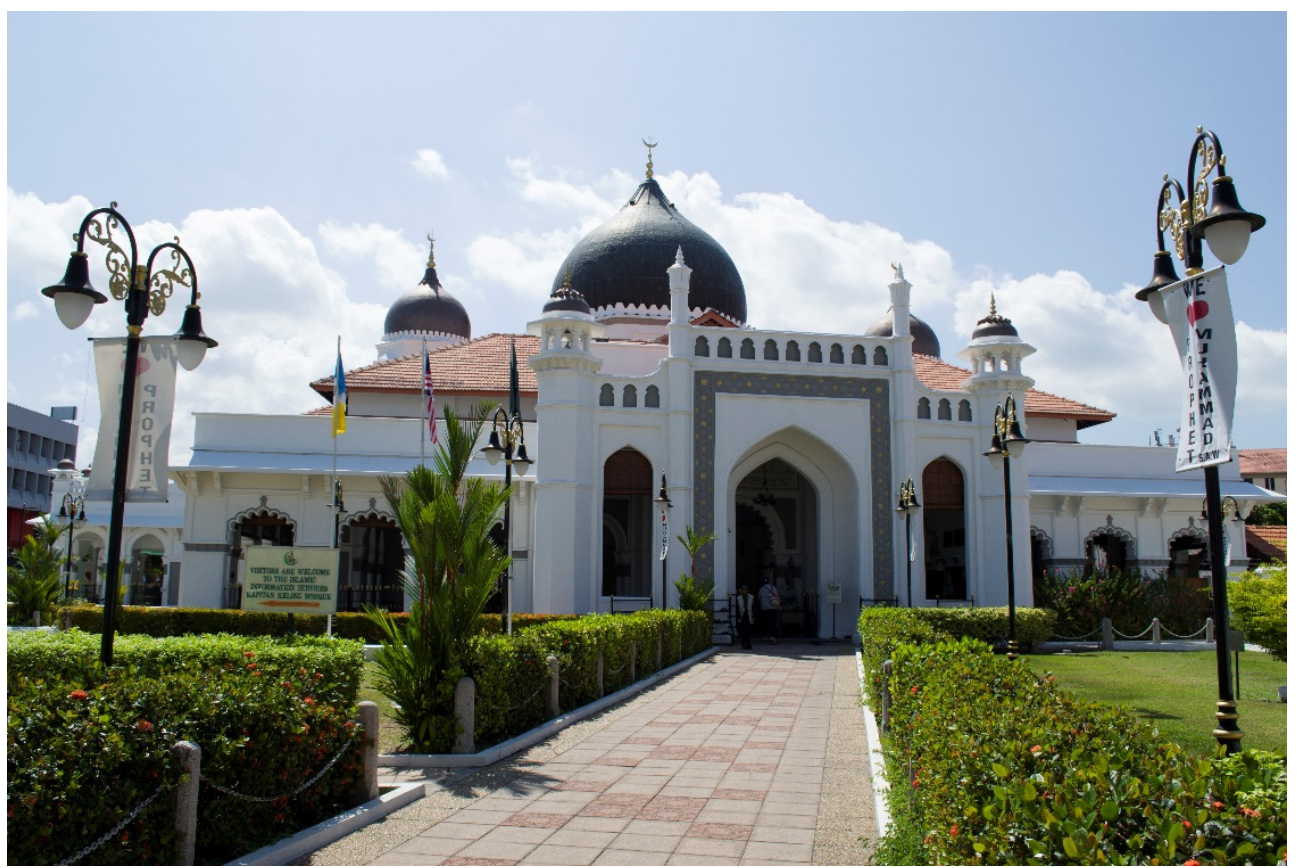

Figure 3. (b) Kapitan Keling Mosque 
Another famously Indian-influenced mosque is Jamek Mosque, which combined Mogul, Moorish and Islamic styles. Built in 1907, it once served as Malaysia's national mosque. Three domes surround the prayer hall with the highest located in the center (Figure 4). Minarets with red and white stripes at a height of 88 feet are located at the corners. Shared similarities also include a fenced-in perimeter; thus, giving it a majestic appearance (Ahmad, 1999).

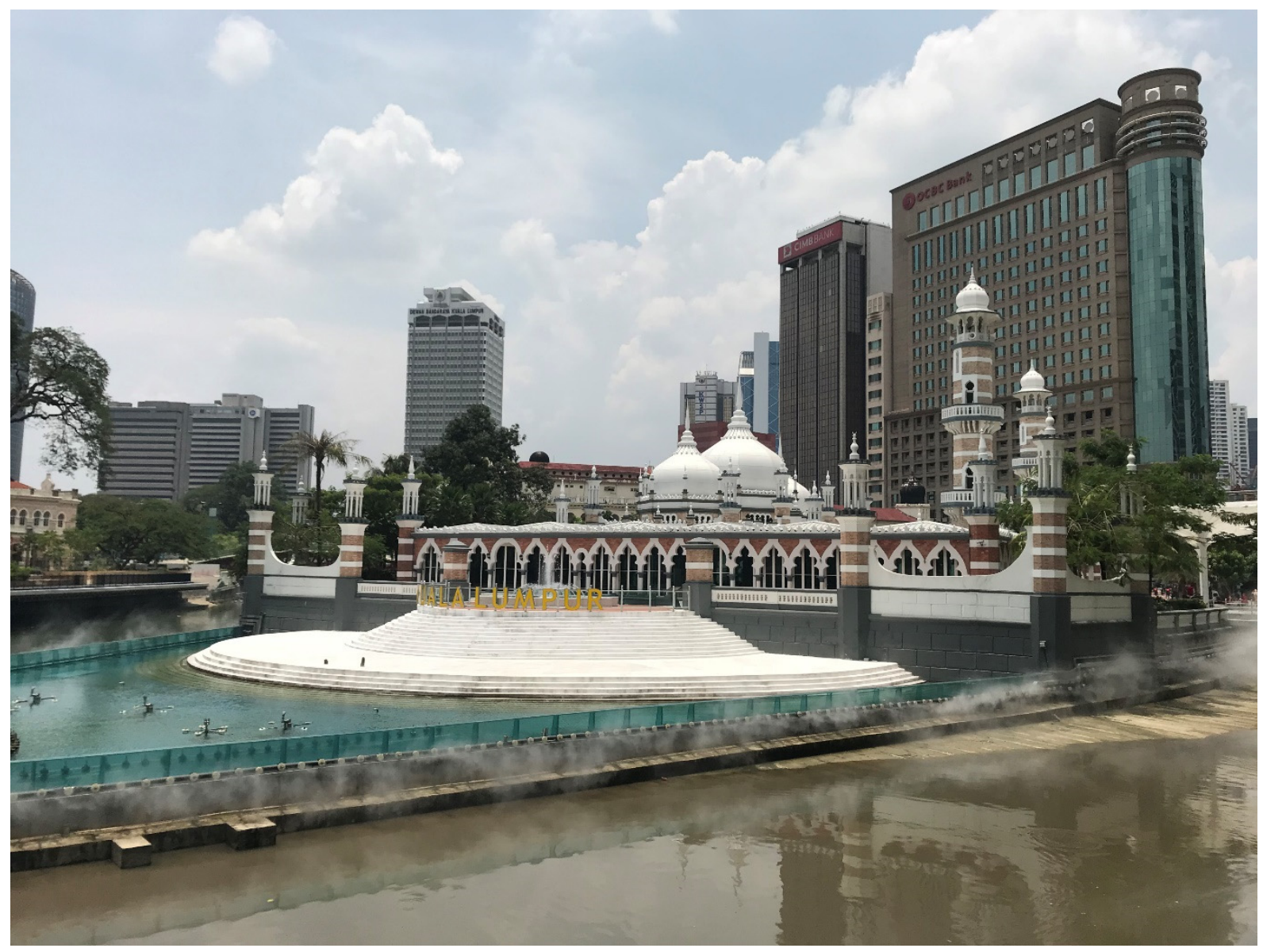

Figure 4. Jamek Mosque

\subsection{Modernized Mosque for a New Nation}

Most mosques in Malaysia implement Moorish/Mogul architecture. However, mosque designs began changing after Malaysian independence in 1957. Increased urban populations and technological advances accelerated the urge to build large-scale mosques. The pride of architects also boosted competition.

The dome of Sultan Salahudin Abdul Aziz Shah Mosque, built in 1988, is recorded as the largest dome in the world with its minarets ranking as the worlds' tallest until 1993. This mosque accommodates 24,000 visitors at a time. Competition between international architects also boosted developments in function and ornamentation, which have remarkably improved (Monem, 2013). Fine Persian calligraphy by Shirazian artists now beautifies its walls and main dome (Figure 5). Blue stained glass panels, a carved wooden pulpit, and an imported marble mihrab brought Malaysian mosque architecture to the next level. This mosque is also equipped with numerous facilities including conference rooms, a library and art galleries (Moser, 2012). 


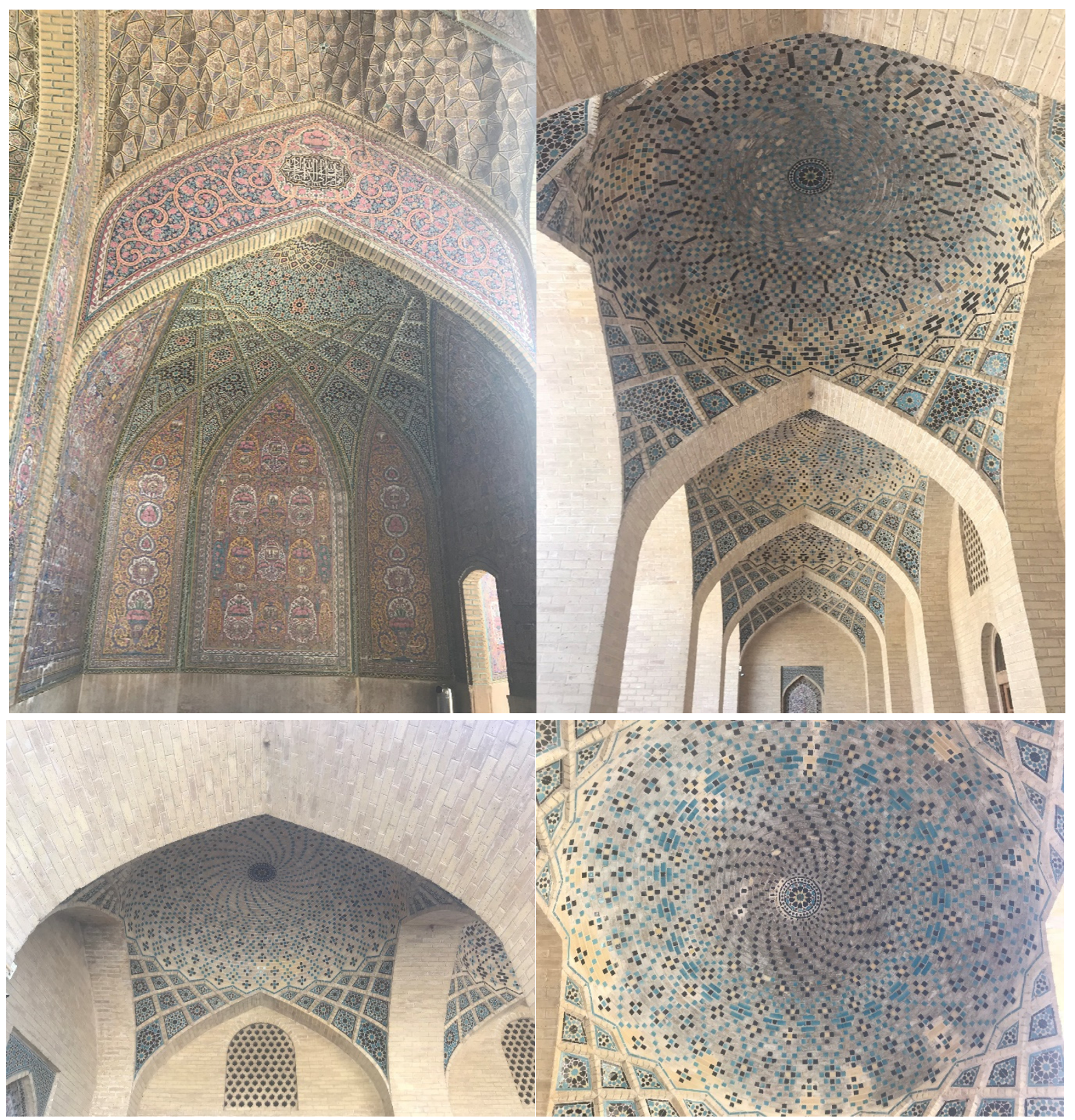

Figure 5. Calligraphy and other ornamentation of the main dome. Mosque Nasir al-Mulk (Masjid Sourati), Shiraz, Iran $(1293-1305 \mathrm{Hj}$; 1876-1888 AD)

Another mosque with stunning architecture is the Crystal Mosque in Terengganu (Figure 6). Built between 2006 and 2008, its steel and glass structure gives it a crystal-like appearance. The mosque comes alive at night when the dome's color alternately changes from pink to green, blue and yellow, causing it to be regarded as one of the most beautiful mosques in the world. In technological terms, Crystal Mosque is also the first Malaysian mosque with its features that enable visitors to access the Internet and read the Quran (John, 2014). 


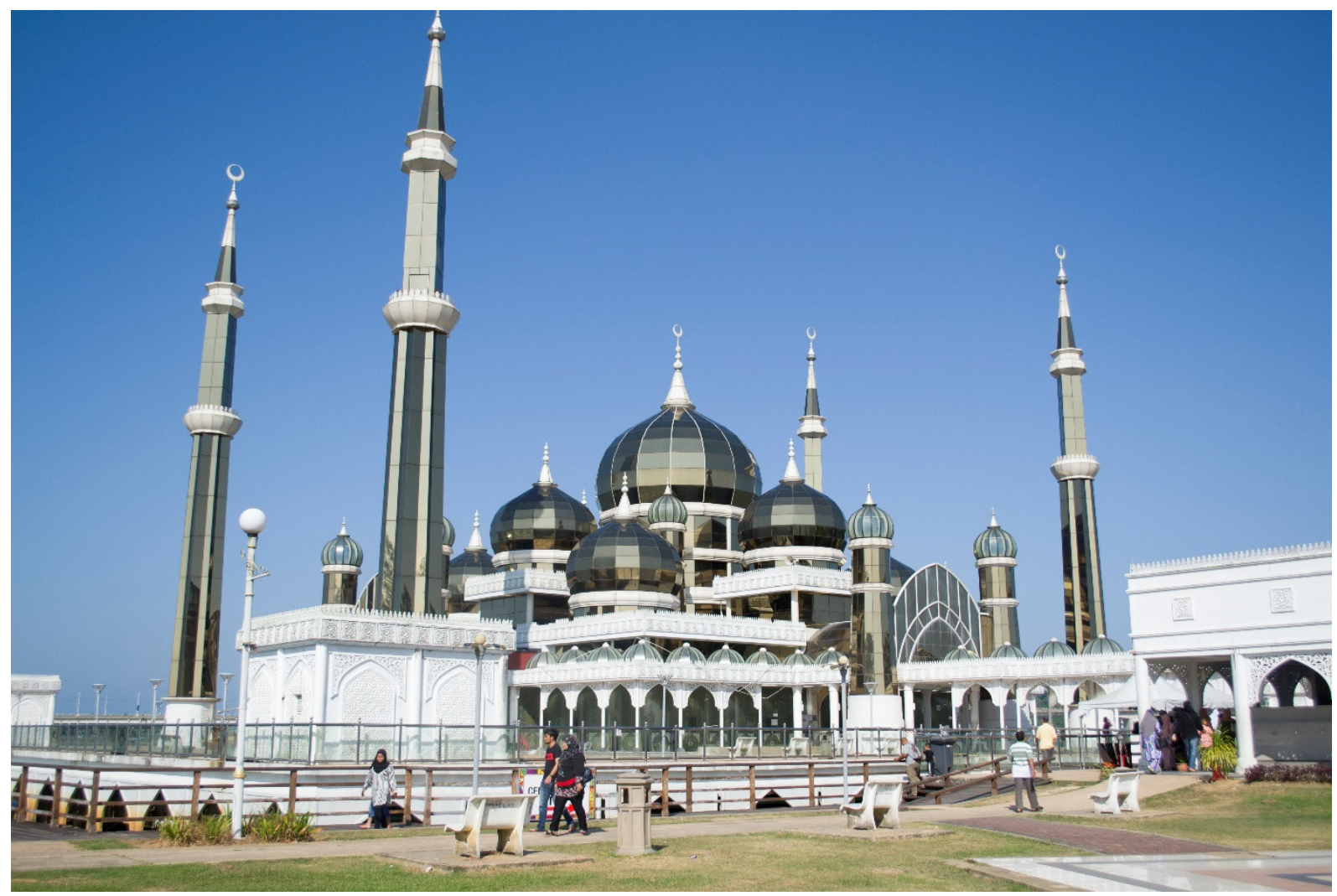

Figure 6. (a) The Crystal Mosque (Terengganu), frontal view

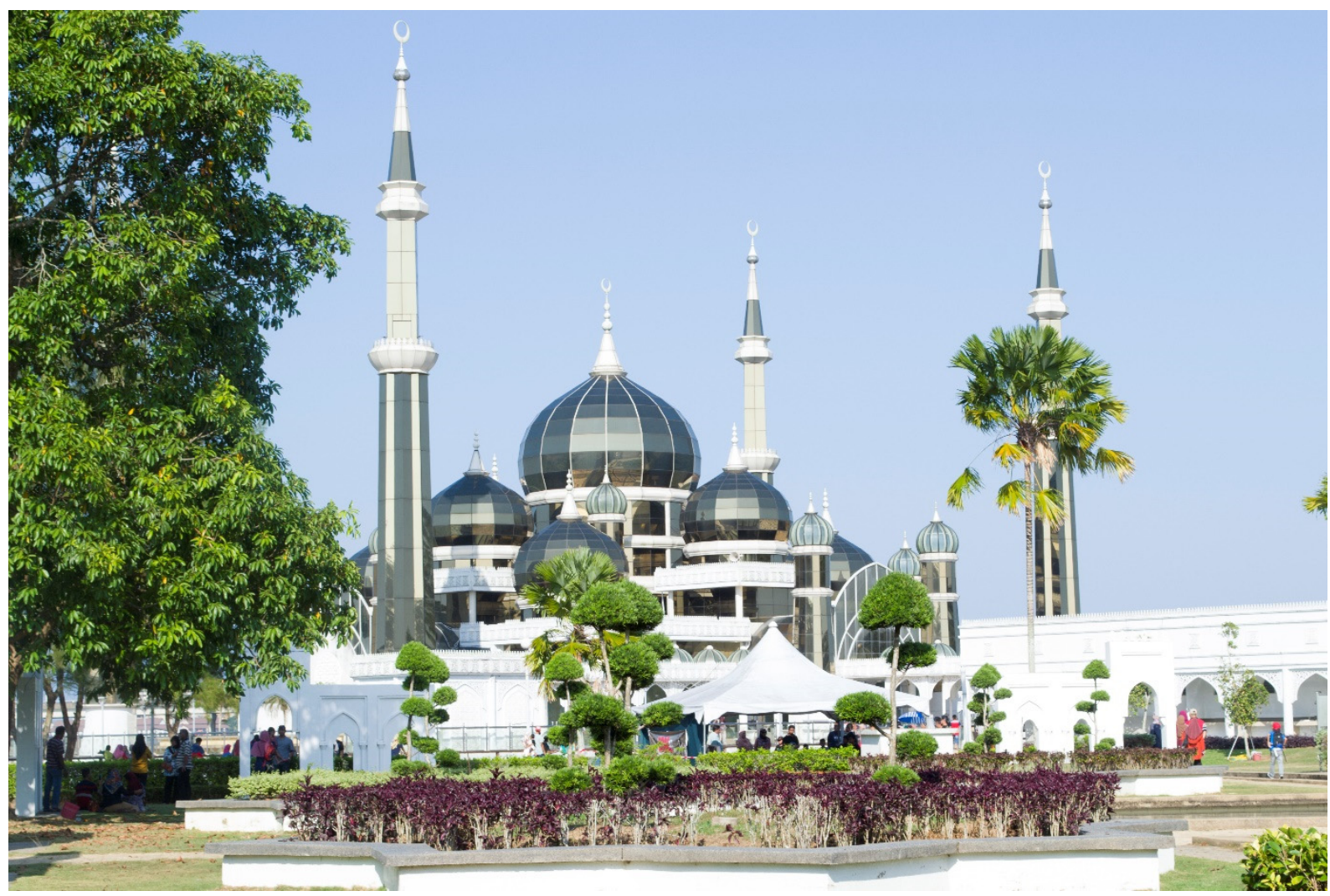

Figure 6. (b) The Crystal Mosque (Terengganu) 
Also, Sultan Salahudin Abdul Aziz Shah mosque which it is located in Shah Alam recognised as Malaysian largest mosque and the second largest mosque in Southeast Asia (Figure 7).

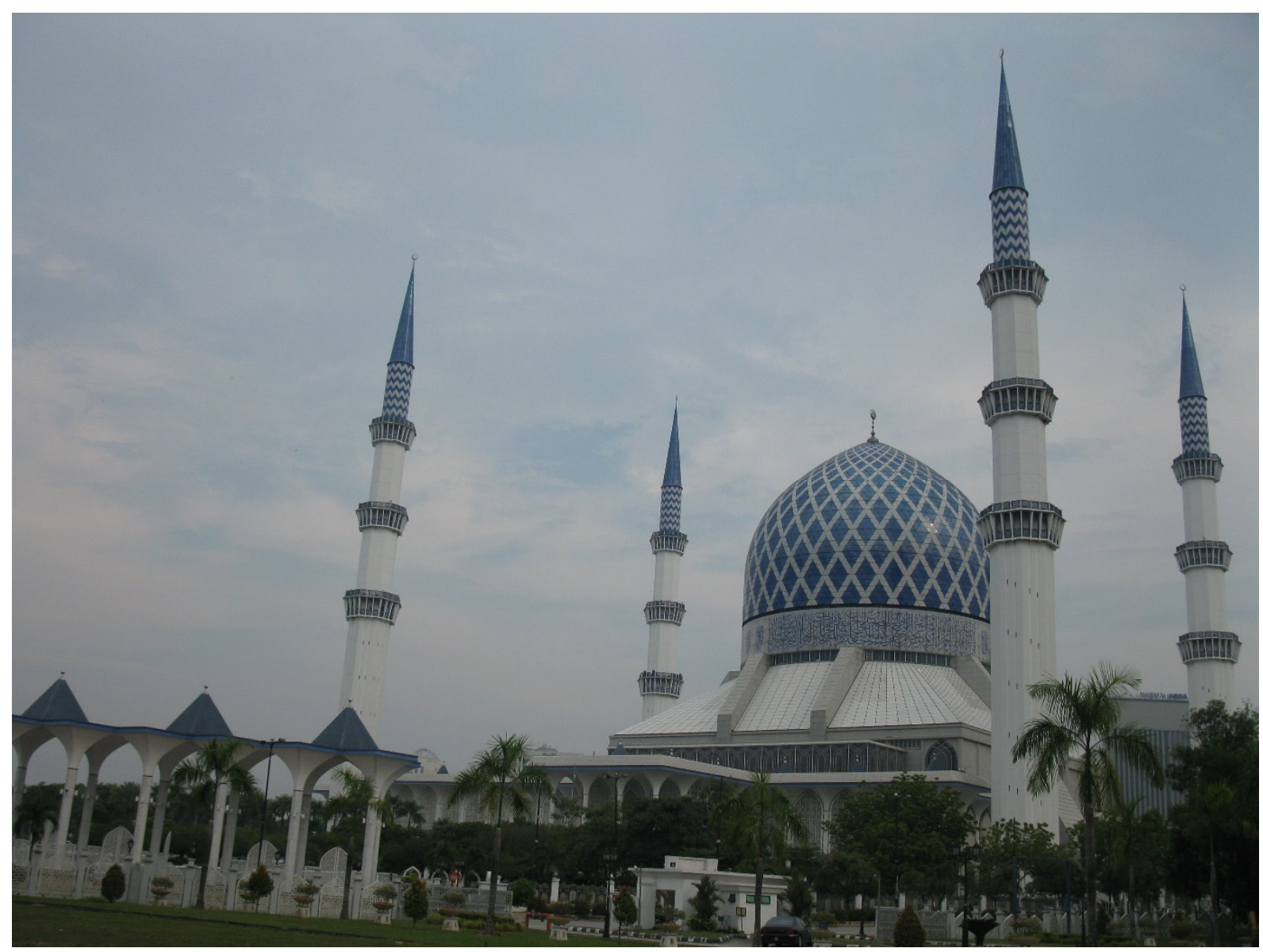

Figure 7. Sultan Salahudin Abdul Aziz Shah Mosque (Shah Alam)

\section{Conclusion}

Architecture is one of the oldest of sciences and describes the structure and design of buildings. In the $7^{\text {th }}$ century $\mathrm{CE}$, Islamic architecture emerged with different styles to present nescient Muslim culture. Major forms of Islamic architecture have historically changed due to regional preferences and cultures of respective Islamic countries. Presently, it is obvious that innovative mosques employ high technology and designs in stark contrast to traditional forms. Modern mosques also have significantly greater capacities to accommodate larger groups than older mosques and can accommodate users with conveniences that facilitate various activities. Indeed Malaysia's multicultural and multi-racial society has ancient roots and magnificent mosques of various architectural styles bearing unique attractions. Symbols of particular racial influences are noted in interior and exterior components of Malaysia's mosques; thus honoring sundry identities while also maintaining the main purpose of every mosque, the worship of Almighty God. As times change, mosque architecture also evolved, becoming even more attractive and modern.

\section{Acknowledgments}

The authors would like to thank the MOE and University Technology of Malaysia (UTM), Research Management Centre (RMC), for $16 \mathrm{H} 48$ and $16 \mathrm{H} 72$ grants that have been supported this research.

\section{References}

All photos of mosques in this article has been taken by the authors.

Al-Quran. 
Abbasali, F. (2011). The Mosque at First Political-Ideological Base in the Islamic Society. Journal of Politics and Law., 4(1), 146-154.

Agius, D. A. (2008). Classic Ships of Islam; From Mesopotamia to the Indian Ocean. Brill: Leiden, Boston.

Ahmad, A. G. (1999). The Architectural Styles of Mosques in Malaysia: From Vernacular to Modern Structures. Proceedings: Symposium on Mosque Architecture: The Historic and Urban Developments of Mosque Architecture, King Saud University, Riyadh, Saudi Arabia., 2, 147-163.

Ahmad, Y., Din, N. C., \& Othman, R. (2013). Mihrab design and its basic acoustical characteristics of traditional vernacular mosques in Malaysia. J. Build. Perform., 4(1).

Allia, J., Nurul, F. H., Yahya, M. H., Zainizam, Z., \& Asnida, A.H. (2013). International Journal of Management, Information, Technology and Engineering, 1(3),15-20.

Avner, R. (2010). The Dome of the Rock in Light of the development of Concentric Martyria in Jerusalem. In Muqarnas: An annual on the visual cultures of the Islamic World (Vol 27). Koninklijke, Leiden: Brill NV (2010): 43-44.

Ayalon, D. (n.d.). Studies in Islamic History and Civilization. P. 370.

Canby, S. R. (2005). Islamic Art in Detail. Harvard University Press, p. 26.

Davidson, B. (1959). The Lost Cities of Africa. Boston: Little Brown, p. 86.

Fischel, W. J. (1952). Ibn Khaldūn and Tamerlane: Their Historic Meeting in Damascus, 1401 AD (803 AH). University of California Press.

Gazalbar, S. (1975). Masjid: Pusat Ibadat dan Kebudayaan Islam (3 ${ }^{\text {rd }}$ Ed.). Jakarta: Pustaka Antara.

Gu, S. (2013). A Cultural History of the Arabic Language. McFarland.

Hassan, A. S. (2010). Islam Came to South East Asia From China: Evidence from Traditional Chinese Roof Design in Kampung Laut's Old Mosque, Malaysia. Can. Soc. Sci., 6(5), 1-15.

Hassan, A. S., \& Nawawi, M. S. A. (2014). Malay Architectural Heritage on Timber Construction Technique of the Traditional Kampung Laut Old Mosque, Malaysia. Asian Soc. Sci., 10(8), 230.

Hitam, M., \& Talib, A. (2005). The Malaysian Mosque: Evolution, Elements \& Meaning. Built Environment Journal, 2(1), 1-10.

Hossein, J. A. (2014). Masjid and Its Management: Issues and Challenges. Proceedings: International Conference on Masjid, Zakat and Waqf (IMAF 2014) (e-ISBN 978-967-13087-1-4). KL, (1-2 Dec.): 58-71.

Ismail S., \& Yusof, A. (2013). MOTIF DAN HIASAN CINA DALAM DEKORASI DALAMAN MASJID: KAJIAN TERHADAP MASJID TUA DI MELAKA PADA AWAL ABAD KE 18. J. Al-Muqaddimah Bil, 2(1), 1-13.

Ismail, M., Rasyid, P., \& Robiah, Y. (2007). Kajian Prioriti Audiens Terhadap Aktiviti Yang Dijalankan oleh Bahagian Dakwah di Masjid Bandar Baru Uda dan Masjid Taman Universiti Johor Bahru. Proceedings: Seminar Kebangsaan Pengurusan Masjid. Skudai, Johor, (28-29 April), 164-177.

Johar, S., Ahmad, A. G., Che-Ani, A. I., Tahir, M. M., Abdullah, N. A. G., \& Tawil, N. M. (2010) Conservation Activities of Old Traditional Mosque in Malaysia: An Overview. Sch. Housing, Build. Planning, Univ. Malaysia, 11, 800 .

John, B. (2014). We Visit Malaysia. Mitchell Lane Publishers, Inc.

King, V. T. (2012). UNESCO in Melaka: Cultural Politics, Identities and Tourism in a World Heritage Site. Leeds East Asia Papers. New Series, No. 4.

Latif, J. (2012). Masjid-Masjid Malaysia: Johor Merintis KecemerlangaN (1 ${ }^{S T}$ Ed.). Usahaniaga Sdn Bhd. Johor.

Malaysia Town and Country Planning Guidelines and Standards (2002). Garis Panduan Perancangan Tempat Ibadat Islam. ( ${ }^{\text {nd }}$ Ed.). Jabatan Perancangan Bandar dan Desa, Malaysia.

Manja, M. L., \& Ahmad, S. M. N. (1995). Aspek-Aspek Kesenian Islam. Dewan Bahasa dan Pustaka, Kuala Lumpur.

Monem, H. A. (2013). Chronology of Multi Minarets in Mosques. J. Archit. Plan. Constr. Manag., 3(2).

Moser, S. (2012). Circulating Visions of High Islam: The Adoption of Fantasy Middle Eastern Architecture in Constructing Malaysian National Identity. Urban Stud., 49(13), 2913-2935. 
Najafi, M., \& Mustafa Kamal, M.S. (2012). Place Attachment To Contemporary Public-Funded Mosques In Malaysia. Alam Cipta., 5(2), 65-76.

Najafi, M., \& Sharif, M. K. M. (2011). Factors influencing public attachment to mosques in Malaysia. International Journal of Architectural Research (IJAR), 5(3), 7-24.

Nasir, A. H. (1984). Mosque of Peninsular Malaysia. Berita Publishing Sdn. Bhd. Petaling Jaya.

Nawawi, Y., Ramlee, R., \& Rashidah, A. D. (2007). Manual Prosedur Kerja (MPK): Kearah Memampatkan Pengurusan Masjid. Proceedings: Seminar Kebangsaan Pengurusan Masjid. Skudai, Johor (28-29 April): 224-237.

Roslan, M. (2007). Pemerkasaan Masjid Melalui Pengurusan Profesional. Proceedings: Seminar Kebangsaan Pengurusan Masjid. Skudai, Johor (28-29 April): 207-213.

Shah, M. A., Arbi, E., \& Inangda, N. (2014). TRANSFORMATION OF MOSQUE ARCHITECTURE IN MALAYSIA: CRITICAL ANALYSIS OF ARCHITECTURAL HISTORY APPROACHES. Proceedings: International Conference on Arabic Studies and Islamic Civilization.

Surat, M., \& Utaberta, N. (2012). Memantapkan Historiografi Masjid Tua Kampung Laut Melalui Analisis Perbandingan Dengan Masjid Agung Demak. J. Islam. Archit., 1(1).

Venugopal, S. N. (2012). The Gaze of the West and Framings of the East [e version]. New York: Palgrave Macmillan.

Vlatseas, S. (1990). A history of Malaysian Architecture. Longman.

Vocabulary of Islamic Architecture. MIT. Online, Retrieved 4 Sep. 2006

WHEBN0000276104 (Article Id), Islamic Architecture. World Heritage Encyclopedia. Accessed 8 March 2018 at http://www.worldlibrary.org/articles/islamic_architecture

Yalman, Suzan. (2001). The Art of the Fatimid Period (909-1171). Accessed 8 March 2016 at http://www.metmuseum.org/toah/hd/fati/hd_fati.htm

Yuseri, A., Naim, A., Marina, M. A. M., \& Azhar, I. R. (2007). Tahap Kemudahan Dan Penggunaan Peralatan Audio-Visual Dan Computer Di Masjid-Masjid Di Bawah Kelolaan Jabatan Agama Islam Selangor (JAIS)Satu Kajian Awal. Proceedings: Seminar Kebangsaan Pengurusan Masjid. Skudai, Johor (28-29 April): 189-195.

\section{Copyrights}

Copyright for this article is retained by the author(s), with first publication rights granted to the journal.

This is an open-access article distributed under the terms and conditions of the Creative Commons Attribution license (http://creativecommons.org/licenses/by/4.0/). 